\title{
Mobility of Goods and People at the Port of Murhum Baubau, 1988-2012
}

\author{
Sabahruddin La Ode Mago, 'Yety Rochwulaningsih, Singgih Tri Sulistiyono \\ Master Program of History, Faculty of Humanities, Universitas Diponegoro \\ Semarang, Central Java, Indonesia
}

DOI: https://doi.org/10.14710/jmsni.v4i2.8060

\begin{abstract}
This paper discusses the mobility of goods and people at the Port of Murhum Baubau during 1988-2012. This port has an important role in the process of mobility of goods and people in Southeast Sulawesi. This paper also addresses the issue of how the mobility of goods and people both in Southeast Sulawesi, national, and international through the Murhum Baubau Port in the period 1988-2012. To analyze these problems, the author applied historical to proof the major development of the Post of Murhum that functions as mobility of goods and people passing the port of Murhum Baubau in regional, national, and international could be studied comprehensively, especially exploring some primary sources that coming from the officials and other institution. In addition, the Port of Murhum is also considered important because it is a

Received:

June 7, 2020

Revised:

December 10, 2020

Accepted:

December 10, 2020

${ }^{*}$ Corresponding Author:

laodemagosabahrudin@live.undip.ac.id gateway for sea transportation, loading and unloading of goods, and transit points for passengers from various regions in Indonesia, both from eastern and western Indonesia. The term of Southeast Sulawesi used in this paper refers to the region between east and south of Sulawesi Island. This region has a strategic position in connecting eastern and western regions of Indonesia. The market commodities from the Baubau region are nickel, asphalt, bitumen, chrome, and fish. In addition, the mobility of goods and people from the Southeast Sulawesi region has a fluctuating increase from year to year.
\end{abstract}

Keywords: Port of Murhum Baubau; Mobility of Goods and People; Market Commodities.

\section{Introduction}

Mobility of goods and people in sea shipping and trade in Indonesia is one of the most important elements in the process of national economic integration. This is closely related to the fact of geographical conditions that the Indonesian archipelago is the largest in the world consisting of about 17,508 large and small islands that are connected so that it is perfectly called the Archipelago State. The landscape of the Indonesian archipelago is a cluster of large islands such as Sumatra, Java, Kalimantan, Sulawesi, Nusa Tenggara Islands, Maluku Islands, and also the western of New Guinea (Papua) Islands, as well as other small islands. These islands spread from Sabang to Merauke along 6,400 kilometers and around 2,500 kilometers from Miangas to Rote Island. The outermost coastline surrounding the Indonesian archipelago is around $81,000 \mathrm{~km}$. About two-thirds of this area is ocean. Historically, this geographical condition has ensured that inter-island shipping and trade have been the key factors in economic development and integration in the Indonesian archipelago (Sulistiyono 2003, 1).

The development of the Port of Murhum Baubau began in a village called Wale village on the banks of Baubau River, in the eastern of Baubau (Rabani 2010, 54). Geographically, it is precisely at the coordinate point of $05^{\circ} 27^{\prime} 24^{\prime \prime}$ south latitude and $122^{\circ} 36^{\prime} 52^{\prime \prime}$ east longitude (Directorate General of Sea Transportation Regional Office VI Kesyabandaran Baubau, 1985). Baubau and the Port of Murhum cannot be separated from the island of Muna which is lied in front of it. Muna Island is the second largest in Southeast Sulawesi Islands region with an area of around $58,845 \mathrm{~km}^{2}$. This island protects the port from waves of western season. Coupled with depth of waters around the jetty, Baubau is known as a port with friendly nature for boats and large vessels to dock. 
This scientific study cannot be separated from the review of previous studies. A review of previous studies is used to find out the limitations so that this study can improve them. Of all the studies on the maritime world, Butonese have not received space or attention from researchers about the mobility of goods and people in the archipelago (Lapian 197). However, there have been a number of scientific papers on the maritime history of Butonese. First, the study conducted by Zuhdi (2018) who has paid considerable attention to the history and political dynamics of Sultanate of Buton. Zuhdi's work on the dynamics of the Sultanate of Buton in dealing with forces such as Goa, Ternate, and VOC / Netherlands, in the concept of allies and enemies in XVII-XVIII centuries. The work is in the form of a book entitled "Sejarah Buton yang Terabaikan: Labu Rope Labu Wana". The second work is Rabani (2010) who has examined the presence of coastal cities in Southeast Sulawesi is inseparable from effects of the port as socio-economic center for local people. Meanwhile, the mobilization of goods and people also reflect on globalization pressure. Wallace argues that opening port means opening borders which influence on economic and social interchanges (Wallace 1999). It also responded by Fariastuti (2014) that works on the opening border of Entikong West Kalimantan. She emphasizes that the opening such facilities compete products between local and foreign commodities and labors. In addition, Jansen (2018) examines port development considers as an inclusive growth which influenced on the novel taxonomy where partnerships between micro-level business strategies and macro-level effects in the port development and economy at large.

This paper examines the position of Port of Murhum Baubau which baceme the mobility of goods and people passing the Port of Murhum Baubau in Southeast Sulawesi in the period of 1988 to 2012. This paper examined the mobility of goods and people in the Port of Murhum Baubau. To focus on the discussion, the research question was raised including how the mobility of goods and people passing the Port of Murhum Baubau in the Southeast Sulawesi Islands region in 1988-2012.

By using historical method, those problems are addressed. The main core of historical method includes heuristics or sources collection, sources criticism, interpretation, and historiography or history writing. The sources collection was performed by library research and document study. The library research was in the form of books and scientific articles written by experts relevant to the research problem. The document study was performed by examining reports obtained from the port of Murhum Baubau and reports from the Central Bureau of Statistics of Southeast Sulawesi, Buton and Baubau.

\section{New Modes of Transportation and Port Developments}

The correlation of sea transportation and land transportation in general is a functional relationship. Functional relation in question is that both become the means used by people to move or transport from one place to another (Hamid 2013). The existence of land and sea transportation modes which are one of the factors supporting the development of the mobility of goods and people is the condition of the road network, public transportation to the hinterland connecting the port area with others such as a settlement center, a plantation center, a trade center, and other community activity centers. Another supporting factor is the increase in the sea transportation fleet connecting inter-islands in the region as an inseparable part of the geographical facts of the archipelago (Sulistiyono 2003).

The assumption is that good road infrastructure and transportation to rural areas and the availability of regular inter-island transportation contribute to the development of mobility of goods and people. Therefore, in the following descriptions, information on the development of the road network, land and sea transportation modes in the period 1988 to 2012 will support the development of the mobility of goods and people in the Port of Murhum Baubau, Southeast Sulawesi.

The road network connecting the regions on the island of Buton with the Port of Murhum is quite adequate and has good quality. The availability of good and adequate road infrastructure results in the mobility of transporting goods and people to the port to run smoothly, as an effort to overcome the problem of transporting both goods and people.

In 1994, the Buton District Government released the development of transportation network construction connecting one place to another including the Port of Murhum Baubau. The distance from sub-district capitals in Buton district to the Buton (Baubau) capital, transportation equipment, cost and duration of trips can be seen in Table 1 . 
According to the Table 1, the condition of the transportation network both land and sea has been built to connect one place to another in the area of Buton District, especially transportation network to the port of Murhum Baubau. This condition has encouraged the sea transportation system in the Port of Murhum with its various activities. Likewise, this condition can facilitate the mobilization of goods and people both from the region to the port of Murhum and vice versa.

Table 1. Distance from the Sub-District Capital to the District Capital of Buton District

\begin{tabular}{lllll}
\hline $\begin{array}{l}\text { District Capital to Sub-District } \\
\text { Capital }\end{array}$ & $\begin{array}{l}\text { Distance } \\
(\mathrm{Km})\end{array}$ & $\begin{array}{l}\text { Transportation } \\
\text { Modes / Vehicles }\end{array}$ & Cost (Rp) & $\begin{array}{l}\text { Travel Time } \\
\text { (hours) }\end{array}$ \\
\hline A. By land & 2 & 3 & 4 & 5 \\
\hline 1. Baubau-Wolio & & & & \\
2. Baubau-Betoambari & 1 & Taxi & 600 & 0.05 \\
3. Baubau-Batauga & 2 & Taxi & 600 & 0.08 \\
4. Baubau-Sampolawa & 24 & Bus & 3.000 & 1.00 \\
5. Baubau-Pasar Wajo & 48 & Bus & 5.000 & 2.00 \\
6. Baubau-Sarawolio & 48 & Bus & 5.000 & 1.50 \\
7. Baubau-Kamaru & 15 & Bus & 1.000 & 0.30 \\
8. Baubau-Kapontori & 91 & Bus & 8.000 & 4.00 \\
9. Baubau-Liabuku & 48 & Bus & 5.000 & 2.00 \\
\hline B. Sea & 11 & Bus & 1.000 & 0.15 \\
\hline 1. Baubau-Wanci & & & & \\
2. Baubau-Kaledupa & 148 & Ship & 18.000 & 13.00 \\
3. Baubau-Tomia & 187 & Ship & 20.000 & 16.00 \\
4. Baubau-Binongko & 226 & Ship & 22.000 & 18.00 \\
5. Baubau-Lombe & 252 & Ship & 25.000 & 20.00 \\
6. Baubau-Mawasangka & 30 & Ferry + Taxi & 5.000 & 2.00 \\
7. Baubau-Dongkala & 67 & Ferry + Taxi & 8.000 & 4.00 \\
8. Baubau-Sikeli & 68 & Ship & 8.000 & 6.00 \\
9. Baubau-Kasipute & 80 & Ship & 10.000 & 9.00 \\
10. Baubau-Boepinang & 82 & Ship & 10.000 & 10.00 \\
11. Baubau-BambaEa & 148 & Ship & 15.000 & 13.00 \\
12. Baubau-Lakudo & 130 & Ship & 15.000 & 11.00 \\
\hline & 39 & Ferry + Taxi & 6.000 & 2.00 \\
\hline
\end{tabular}

Source: The Central Bureau of Statistics of Baubau 1995, 1.

The port as a means of sea transportation is part of the transportation system in general. The port cannot be separated from the land transportation system because both have a functional relationship of which the role is as a connecting bridge between land and sea. In the land transportation system, there are a number of transportation fleet facilities that can be used such as motorized vehicles and non-motorized vehicles. Motorized vehicles are such as cars and motorbikes, and non-motorized vehicles are such as tricycles, bicycles and carts. Various types of vehicle fleets in the land transportation system play an important role. In addition to being able to be used by the community as passenger transportation, this land transportation facilities can also be used as transportation of agricultural production, forestry products, and other products in relation to trade to and from the port.

Transportation services to and from the port of Murhum Baubau are generally provided by individuals, private, and the government. Types of inner cities transportation includes motorcycle, taxi, and rickshaw. Types of transportation for out of town includes microbus cars, pick up cars, cars, buses, and trucks. The condition found in the field is that transportation outside the city in the form of a microbus that goes to the Murhum Baubau Port has a double function. In addition to being used as passenger transportation, it is also used to transport products, especially in the field of trade in agricultural products. However, the amount of cargo always exceeds the capacity due to the number of pick up cars that have decreased (Murhum Baubau Port Administration 1989). To transport the products in greater quantities and to transport forest products, the truck transportation type is used.

Geographically, the port of Murhum Baubau has a strategic position because it is in the national shipping and trade lane connecting eastern and western of Indonesia. In addition, the Southeast Sulawesi Islands connect a group of small islands in this waters area. Community settlement of 
Southeast Sulawesi Islands are commonly spread along the coast. The significance of the waters of Southeast Sulawesi is very prominent in maritime areas such as the Southeast Sulawesi Islands in which the width of the largest island has a diameter (the widest part) from east to west $\pm 28 \mathrm{Km}$ (Malihu 1998, 50). Therefore, there are no hinterland areas throughout the Southeast Sulawesi Islands geographically that are closed from the effect of sea (waters, the sea is a much broader than the land area).

As an archipelago with good waters has encouraged the development of sea transportation fleet as a bridge between one island to another, the mobility of goods and people in the area becomes effective and efficient. The number of sea transportation fleet flows has experienced a very significant development since 1988. This article describes how the development of ship visits number at the Port of Murhum Baubau in the period 1989-2012.

Sea transportation is an important facility and infrastructure in Indonesia as an archipelagic state to accelerate the economic wheels of the community in inter-island or regional trade (Lasse 2015, 3). As a maritime nation, Indonesia cannot be separated from the availability of port infrastructure and means of sea transportation to connect human mobility and the flow of goods in distributing merchandise, especially for the daily needs of people in each region including Baubau (Sudjiton 2012). In distributing merchandise to each region or inter-island, the people of Baubau mostly use the sea route passing the Port of Murhum (The Central Bureau of Statistics of Baubau 2000, 214). The important role of sea transportation in the Port of Murhum is still very dominant in supporting the smooth goods and passenger transportations as well as connecting between one island to another around Baubau and outside Baubau. The port of Murhum as one of the major and most important port in Southeast Sulawesi serves as a gateway for sea transportation, a place for loading and unloading of goods, and transit points for passengers from various regions in Indonesia, both from eastern and western of Indonesia (The Central Bureau of Statistics of Baubau 2005, 216). The smooth sea transportation visit at the Port of Murhum results in economic activities at this port increasingly crowded both goods loading and unloading activities as well as embarkation or debarkation activities. Ships anchored at the Port of Murhum are usually cargo ships and passenger ships, such as the Tidar, Rinjani, Tilongkabila, Dorolonda, Ciremai, Dobonsolo, and other ships. The high level of visits by these vessels also contribute to the development of the Port of Murhum.

Ships as sea transportation are a very effective and cheapest means that can be achieved by all in connecting inter-island transportation (Gondhokusumo 1982, 3). This basic assumption can be related to the flow of ship visits at the Port of Murhum Baubau that continues to increase.

In 1998 to 1999, this port experienced a significant decline, the number of ship visits was by $4.58 \%$. One of the reasons was the impact of crisis from mid-1997 to the end of 1998 (Southeast Sulawesi Provincial Government 1999, 3). Ship visits began to increase again from 2000 to 2012.

The number of ship visits decreased by $5.08 \%$ in 2002 compared to 2001, from 5,186 to 5,071 ship visits. One of the reasons was the impact of the country's political uncertainty during the middle of 1999 to 2001, so that people had to think twice about having to travel without urgent needs (Southeast Sulawesi Provincial Government 2002, 312). Then in 2003 to 2005, the chart of ship visits increased but the number of ship visits in 2006 was recorded as many as 6,569 visits, falling to $3.65 \%$ compared to 2005 by 6,818 visits (Baubau Regional Government 2007, 220). In 2007 to 2012 , the number of ship visits continued to increase until it reached 8,243 visits in one year.

\section{New Port Construction}

Mobilization of goods and people enhancement at the Port of Murhum Baubau is inseparable from the existence of new ports playing as hinterland or hintersea, areas, making it easier for shipping and inter-island trading activities. These new ports are work units or under the guidance of the Port of Murhum Baubau. The ports included in the work scope of sea transportation operation unit offices are as follows: a.) Boepinang Port, b.) Sikeli Port, c.) Wanci Port, d.) Kasipute Port, e.) Kaledupa Port, f.) Lawele Port, g.) Liana Banggai Port, h.) Talaga Raya Port, i.) Siompu Port, j.) Wamengkoli Port, k.) Batu Atas Port, l.) Kadatua Port, n.) Lasalimu Port, m.) Pasarwajo Port, o.) Tomia Port, p.) Binongko Port, q.) Ereke Port, r.) Burunga Port, s.) Jembatan Batu Baubau Port, as well as t) PT ASDP Baubau Port (Port of Murhum Baubau Administration, 2012a). Look at Figure 1. Position and route of ports in the Southeast Sulawesi Islands region. 
The Port of Murhum Baubau also has several special ports including: PT Pertamina, PT. Arahon, PT. Terias Jaya Agung, PT. Bumi Inti Sulawesi, PT. Tima Explomin, PT. Anugrah Harisma Barakah, PT. Arga Morin Indah, PT. Bumi Buton Delta Mega, and PT. Harmoni Energi Indonesia (Murhum Baubau Port Administration 2012b).

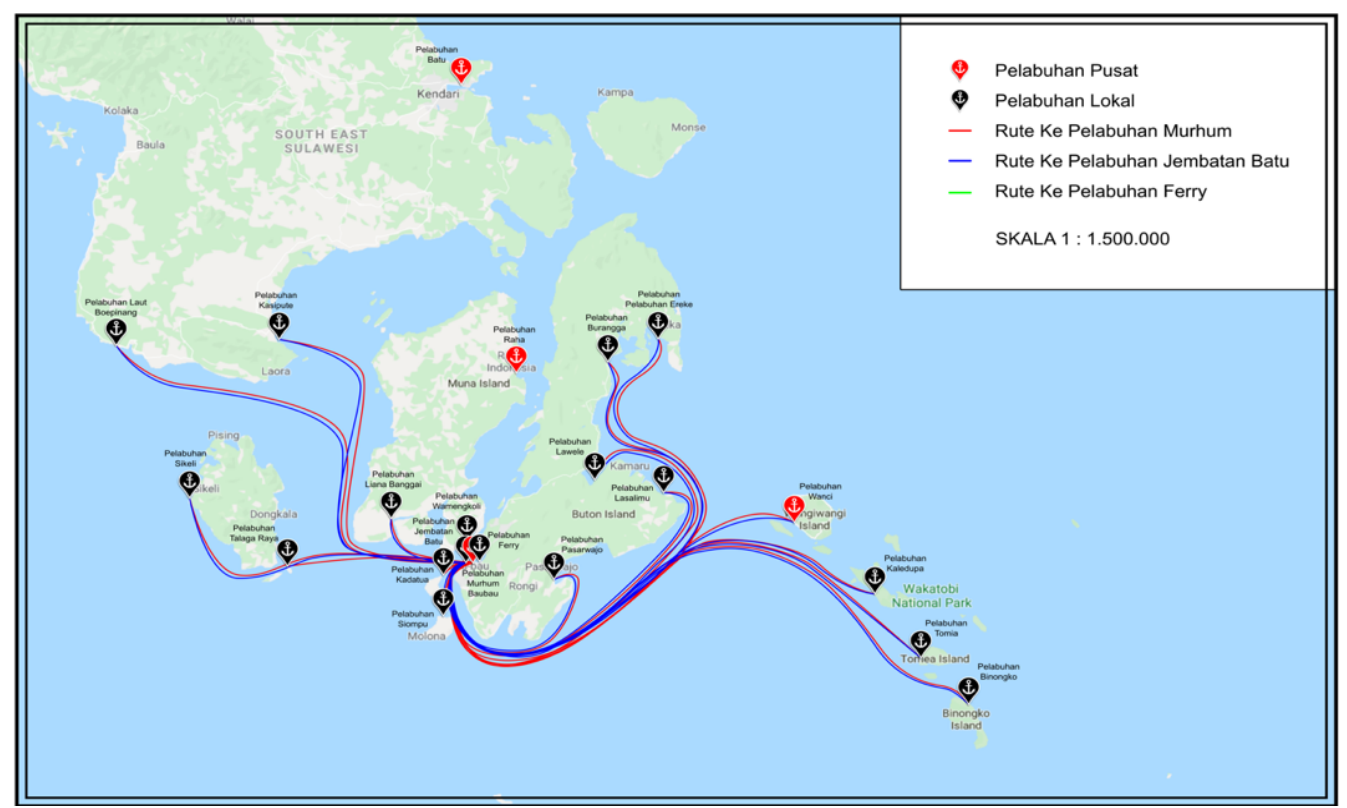

Figure 1. Position and route of ports in the Southeast Sulawesi Islands region.

\section{Mobility of Loading and Unloading of Goods Passing the Port of Murhum Baubau 1988-2012}

Mobility of loading and unloading of goods passing the Port of Murhum Baubau is an indicator in the economic activity of a region. In this research, to determine the economic activity of a region, it must measure the loading and unloading volume in tons. Goods loading and unloading activities passed the Port of Murhum Baubau in 1988-2012. It was divided into two periods; the first period from 1988 to 1999 and the second period from 2000 to 2012.

The mobility of loaded and unloaded goods at the Port of Murhum Baubau from 1988 to 1999 had a quite varied increase. During this period, the volume of unloading goods had a very great amount compared to the loading volume. The average amount of annual volume of unloading was 56,017 tons, while the average annual volume of loading was only 16,826 tons. This indicated a distant interval. The overall annual volume of loading and unloading was 72,844 tons. The loading and unloading volumes as shown in Figure 2 and Figure 3. Figure 2 illustrates the volume of loading and unloading of goods passing the Port of Murhum Baubau in the period 1988 to 1999.

Figure 2 shows that the volume of loading and unloading of goods passing the Port of Murhum Baubau had a fluctuating increase in which from 1988 to 1990 the volume of unloading increased but in 1991 decreased, then in 1992 and 1993 it increased more. In 1994 to 1998, it continued to increase. However, in 1999 there was a very significant decrease. One of the causes was the impact of the country's political uncertainty situation in 1999 that the people had to think twice if they had to shop without urging needs (Southeast Sulawesi Provincial Government 2012, 312). 


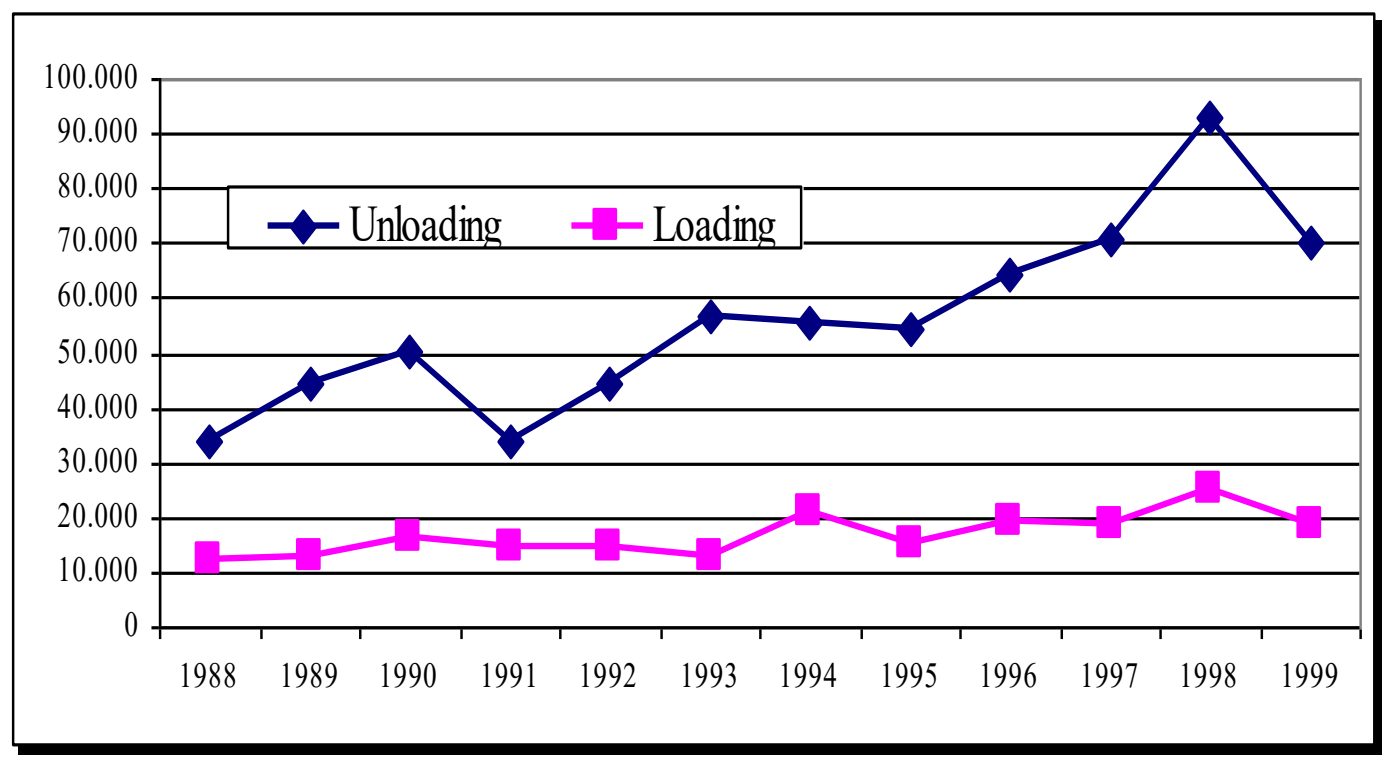

Figure 2. Volume of Unloading Goods Passing the Port of Murhum Baubau in 1988-1999 (in tons) Source: Murhum Baubau Port Administration 1999.

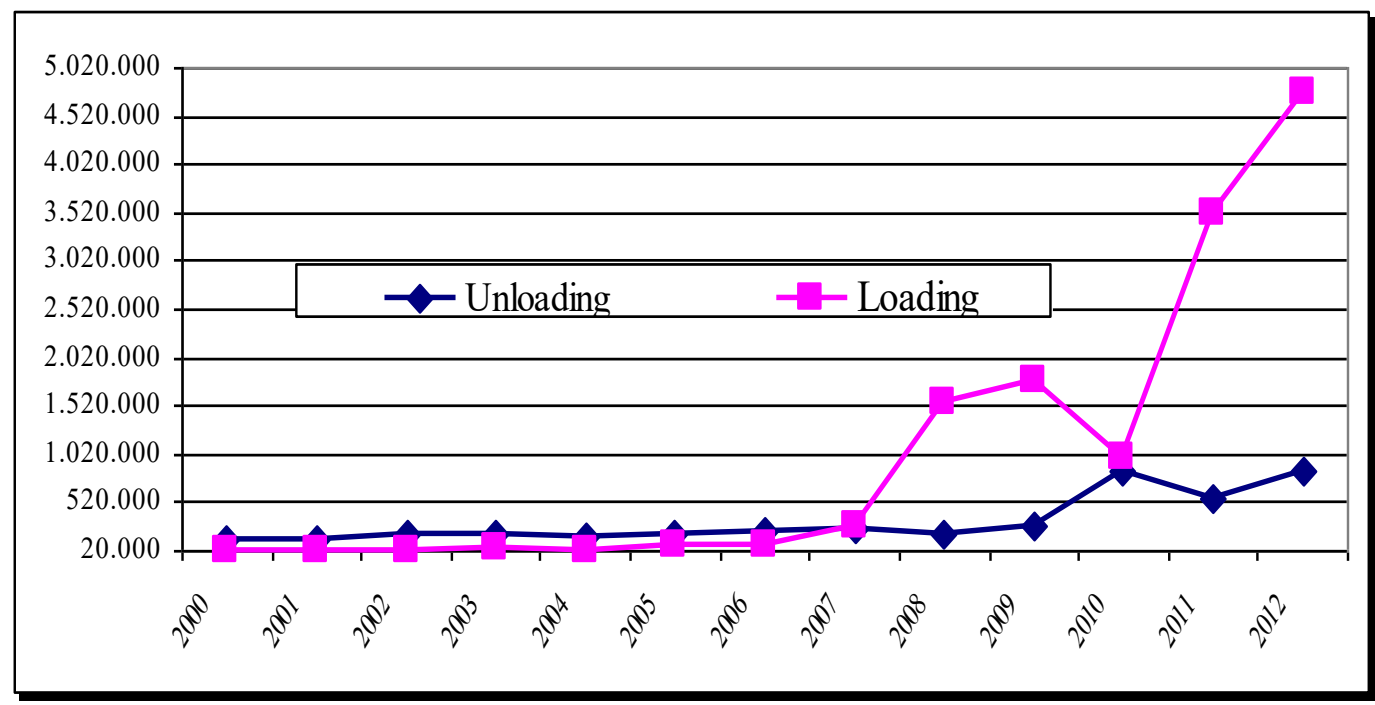

Figure 3. Volume of Loading and Unloading of Commodities Passing the Port of Murhum Baubau in 2000-2012 (in tons)

Source: Murhum Baubau Port Administration 2012c; The Central Statistics Bureau of Baubau 2012.

Figure 3 shows that the volume of loading and unloading of commodities via the Port of Murhum Baubau continued to increase. In 2000 to 2007, the number of unloading volumes was higher when compared to the loading volume. However, from 2008 to 2012 the loading volume was higher when compared to the loading volume. Figure 3. shows that the people's economy in the Southeast Sulawesi Islands region increased, especially in terms of productivity as seen from 2008 to 2012. This situation also changed the mobility of goods in the Port of Murhum Baubau from consumers to producers. One of the reasons was the existence of new ports that facilitate inter-island shipping and trading activities in the Southeast Sulawesi Islands.

\section{The Mobility of Passengers at the Port of Murhum Baubau, 1988-2012}

In addition to distributing goods, the Port of Murhum Baubau also plays a role in the mobility of people or passengers who transit at the Port of Murhum Baubau. The Port of Murhum Baubau is located in the shipping lane both to the western and eastern of Indonesia. This strategic geographical condition facilitates the mobilization of people or passengers in the Southeast Sulawesi Islands. 
Southeast Sulawesi Islands people has significant role for people mobilization in Indonesia, especially in the eastern of Indonesia. Geographical facts of the Southeast Sulawesi Islands region, especially Buton which has arid and rocky land, encourage the community to work in other places. However, mobilization of people to various places, especially to eastern of Indonesia to get work, cannot only be seen from the economic context. There are cultural urge showing that migration has strongly embedded in community groups in Indonesia including Bugis, Buton, and Minangkabau tribes. In maritime world, there are three maritime ethnic groups known as the BBM acronym (Bugis, Buton, Makassar) because they have a very thick migration tradition. In this cultural context, young people have higher expectations to go sailing out of their social groups for a certain period of time. This expectation drives young people to leave their hometowns (Zuhdi 2014, 246).

Therefore, passengers who leave the Port of Murhum Baubau will always be far more ("in a safe country") compared to passengers who drop off at this port. The number of passengers who embarked and disembarked at the Port of Murhum Baubau from 1988 to 1999 had a fluctuating increase in 11 years. The number of passengers who embarked were 2,011,571 people and passengers who disembarked were $1,831,380$ people, that a total of people who did not return were 180,191 . These figures are as shown in Figure 4.

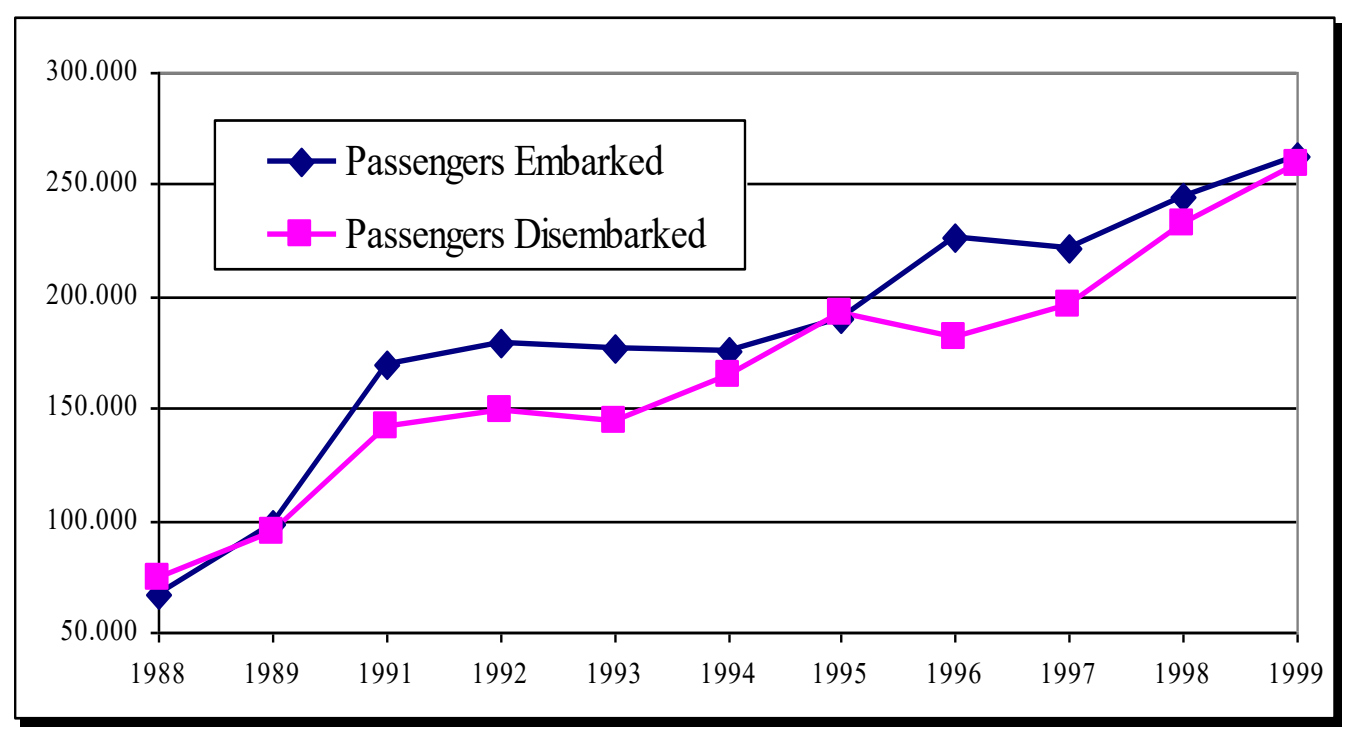

Figure 4. Number of Passengers who Embarked / Disembarked through the Port of Murhum Baubau in 1988-1999.

Source: Murhum Baubau Port Administration 1999.

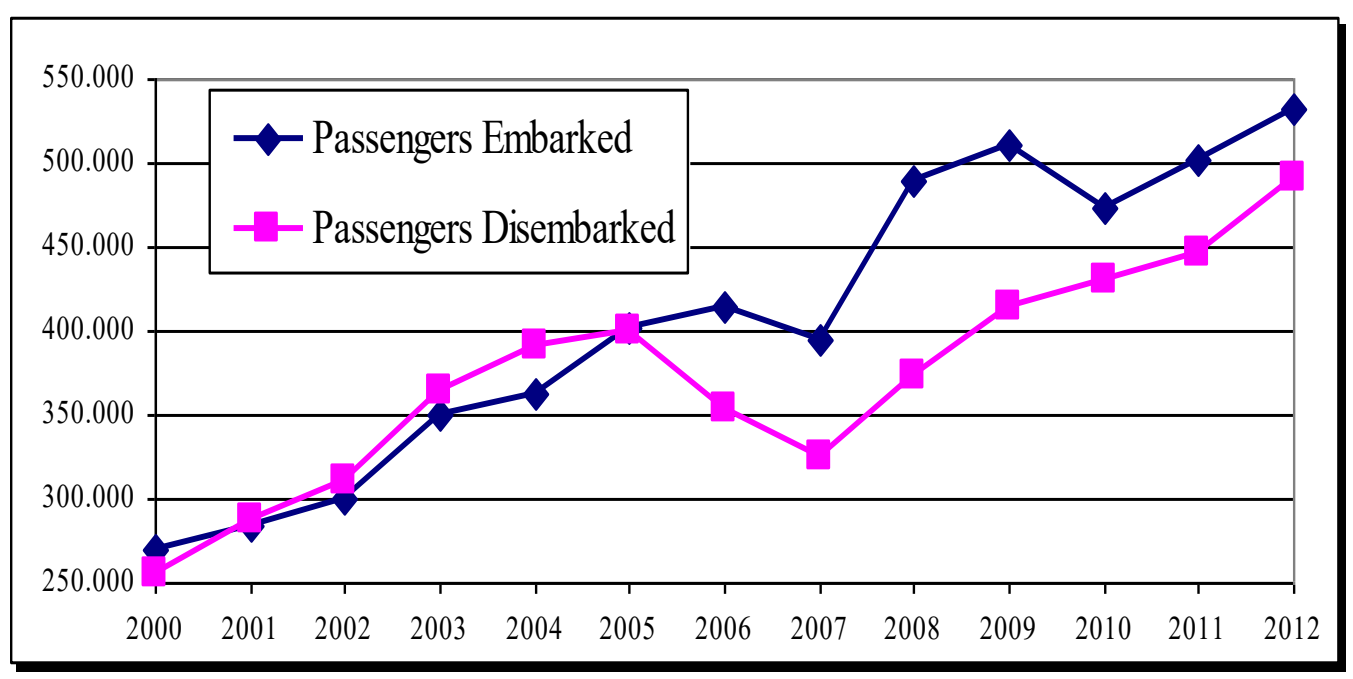

Figure 5. The Embarked/ Disembarked Passengers via the Port of Murhum Baubau, 2000-2012.

Source: Murhum Baubau Port Administration 2006; The Central Bureau of Statistics of Baubau 2009; Murhum Baubau Port Administration 2011. 
The flow of passengers who disembarked and embarked at the Port of Murhum Baubau from 2000 to 2012 is shown in Figure 5. The number of passengers who disembarked at the Port of Murhum Baubau from 2001 to 2005 was far more than the passengers who disembarked or embarked at the port. This condition was certainly different from the period of 1988 to 1999 . The increase in the number of passengers disembarked at the Port of Murhum Baubau was caused by inter-religious conflicts in Maluku in 1999-2001 (Van Klinken 2007, 171-174). Refugees due to the conflict in Maluku made the Port of Murhum Baubau as their main destination for escape. The total number of refugees who disembarked at the Port of Murhum Baubau was around 34,000 families (Dhakidae et al. 2003, 606).

Increased passenger flow who embarked than who disembarked occurred again in 2006 to 2012. This happened due to the conflict that had died down. Although in 2001 to 2005 the number of passengers disembarked was more than passengers who embarked. But overall, the number of passengers who embarked was still more than passengers who disembarked by a difference of 167,510 people over the past 12 years. This number decreased if compared to the period of 1988 to 1999 reaching 180,191 people. Thus, the mobility of Southeast Sulawesi islands communities such as the Butonese, the Muna and Wakapbi tribes is circularly outward mobility so that most of the migrants return to their area of origin (Rabani 2010, 82). The people of Southeast Sulawesi Islands migrate to trade through shipping so that the main occupation of the Butonese lies in terms of trade, shipping and maritime. This is almost similar to the trading form of the Minangkabau people (Naim 1973, 154-156). However, the majority of the Butonese overseas are in eastern of Indonesia.

\section{Mobility of Goods and People from Local Ports to Baubau, 1991-2012}

Regarding the mobility of goods and people from local ports to Baubau or vice versa, this discussion is divided into two periods, namely the period of 1991 to 1999, and the period of 2000 to 2012. Each period is divided into two tables, namely the mobility table of goods and the mobility table of people or passengers. The numbers in the table provide an idea of how the mobility of goods and people took place at local ports to Baubau, Southeast Sulawesi Islands. Whether the geographical conditions and certain periods affected the loading and unloading of mobility of goods and people and how that happened.

Table 2. Mobility of Goods from Local Ports to Baubau and vice versa 1991-1999

\begin{tabular}{|c|c|c|c|c|c|c|c|c|c|c|}
\hline \multirow{4}{*}{ Port } & \multicolumn{10}{|c|}{ Goods Mobility } \\
\hline & \multicolumn{5}{|c|}{ Unloading } & \multicolumn{5}{|c|}{ Loading } \\
\hline & \multicolumn{5}{|c|}{ Year } & \multicolumn{5}{|c|}{ Year } \\
\hline & 1991 & 1993 & 1995 & 1997 & 1999 & 1991 & 1993 & 1995 & 1997 & 1999 \\
\hline Wanci & 1.588 & 1.605 & 3.906 & 2.355 & 3.768 & 378 & 247 & 259 & 1.022 & 1.461 \\
\hline Boepinang & 262 & 672 & 209 & 38 & 5.063 & 266 & 561 & 407 & 226 & 335 \\
\hline Kasipute & 192 & 548 & 464 & 779 & 834 & 258 & 730 & 790 & 916 & 786 \\
\hline Sikeli & & 2.991 & 1.466 & 2.565 & 1.709 & & 2.704 & 1.181 & 2.699 & 1.028 \\
\hline Talaga & & 69 & 217 & 318 & - & & 163 & 170 & 140 & - \\
\hline Lasalimu & & - & - & - & 251 & & - & - & - & 13.455 \\
\hline Kaledupa & & 1.274 & 723 & 754 & 2.778 & & 145 & 267 & 651 & 668 \\
\hline Tomia & & 237 & 420 & 467 & 496 & & 4 & 23 & 36 & 3 \\
\hline Binongko & & 48 & 63 & 113 & 108 & & 41 & - & - & - \\
\hline Jembatan Batu & 2.296 & 5.639 & 4.363 & 3.242 & 1.435 & 1.243 & 2.894 & 4.715 & 3.727 & 2.571 \\
\hline
\end{tabular}

Source: Murhum Baubau Port Administration 1999. "Data Kegiatan Angkutan Laut pada Kantor Pelabuhan Murhum Baubau Tahun 1988-1999.” 
From Table 2, it is known that the mobility of goods both unloading and loading in 1991 was only performed by four ports namely the ports of Wanci, Boepinang, Kasipute, and Jembatan Batu. The three first ports are outside of Buton Island while Jembatan Batu Port is on Buton Island, which is \pm 500 meters from the Port of Murhum Baubau. Jembatan Batu Port does not operate goods mobility to and from the Port of Murhum Baubau. However, Jembatan Batu Port is a place for small ships to unload goods and transit passengers from various ports in the Southeast Sulawesi Islands to Baubau. Next, it is going to the Port of Murhum Baubau by land transportation.

Between 1993 and 1999, the Port of Murhum Baubau had 10 working unit ports. Of the 10 ports, 8 ports were outside of Buton Island, only Jembatan Batu and Lasalimu Ports were on Buton Island. Lasalimu Port was located in the eastern of Buton Island (Murhum Baubau Port Administration, 2012a). Of the ten ports, there were dynamic mobility patterns that sometimes go up and down. There is something interesting from Table 4.2, almost all ports show that average of unloading volume was more than loading volume, only Lasalimu Port had higher loading volume than the unloading. There are several reasons: 1) Lasalimu Sub-district is an area on Buton Island which has fertile land just below the foot of Mount Lambelu so that it has abundant agricultural and agricultural products, 2) The plantation and agricultural products are marketed to Baubau using sea transportation, 3) Land transportation is very limited even no one can transport the agricultural products of the community. For the number of passenger mobility who disembarked or embarked from smaller ports to the Port of Murhum Baubau or vice versa from 1991 to 2012, it is shown in Tables 2 and 3.

Table 3. Mobility of Passengers from Local Ports to Baubau and vice versa 1991-1999

\begin{tabular}{|c|c|c|c|c|c|c|c|c|c|c|}
\hline \multirow{4}{*}{ Port } & \multicolumn{10}{|c|}{ Mobility of Passengers } \\
\hline & \multicolumn{5}{|c|}{ Disembarked } & \multicolumn{5}{|c|}{ Embarked } \\
\hline & \multicolumn{5}{|c|}{ Year } & \multicolumn{5}{|c|}{ Year } \\
\hline & 1991 & 1993 & 1995 & 1997 & 1999 & 1991 & 1993 & 1995 & 1997 & 1999 \\
\hline Wanci & 8.070 & 5.339 & 13.389 & 31.048 & 54.240 & 6.906 & 4.732 & 15.365 & 31.545 & 53.383 \\
\hline Boepnang & 913 & 1.865 & 3.895 & 4.563 & 5.944 & 1.022 & 1.923 & 3.824 & 4.564 & 5.769 \\
\hline Kasipute & 256 & 4.105 & 5.245 & 4.632 & 4.730 & 280 & 3.558 & 4.961 & 4.623 & 4.758 \\
\hline Sikeli & - & 9.111 & 7.952 & 5.663 & 8.503 & - & 10.459 & 9.276 & 5.552 & 8.432 \\
\hline Talaga & - & 796 & 2.074 & 1.522 & 4.707 & - & 892 & 2.121 & 1.917 & 4.722 \\
\hline Lasalimu & - & 1.131 & 5.209 & 10.234 & 49.526 & - & 1.181 & 5.887 & 12.020 & 51.049 \\
\hline Kaledupa & - & 802 & 1.798 & 2.261 & 3.903 & - & 940 & 1.461 & 2.822 & 3.422 \\
\hline Tomia & - & 488 & 1.327 & 3.902 & 3.497 & - & 488 & 1.641 & 3.896 & 2.964 \\
\hline Binongko & - & 489 & 436 & - & 181 & - & 464 & 398 & - & 123 \\
\hline $\begin{array}{l}\text { Jembatan } \\
\text { Batu }\end{array}$ & 20.466 & 28.026 & 24.799 & 17.989 & 10.643 & 17.386 & 28.586 & 24.903 & 18.059 & 11.033 \\
\hline
\end{tabular}

Source: Murhum Baubau Port Administration 1999.

Based on Table 3, it is known that passenger mobility from local ports to Baubau or vice versa began to increase since 1993 both in the number of loading or unloading and the number of passengers. From 10 ports, it was only 3 ports having a very high level of passenger mobility, namely Wanci Harbor, Lasalimu, and Jembatan Batu. At the Port of Wanci, from 1991 to 1993, the number of passengers who disembarked was more than the embarking, but the number of passengers embarking was more than the number of passengers who disembarked in 1995 to 1997 . Then in 1999, the number of passengers who disembarked was more than those embarking. This caused a conflict in the Maluku Islands so that the migrants decided to return to their hometowns (Dhakidae 2003, 606).

Passenger mobility at the Port of Lasalimu had consistently increased for both who disembarked and embarked. Passengers who embarked through the Port of Lasalimu from 1993 to 1999 were more than passengers who disembarked. This was caused by the people who used Lasalimu Port to go to 
Baubau by Sea Fleet. However, a small portion of the community returned to Lasalimu by land transportation. This was similar to the mobility at Jembatan Batu Port. The number of passengers who embarked was more than those who disembarked. This was caused by passengers who disembarked at the Port of Murhum Baubau from both eastern and western of Indonesia to cross to other local ports using ships that docked at Jembatan Batu Port. The mobility of passengers from local ports to Baubau or vice versa in 2000 to 2012 can be seen in Table 4 .

Table 4. Mobility of Passengers from Local Ports to Baubau vice versa 2000-2012

\begin{tabular}{|c|c|c|c|c|c|c|c|c|c|c|}
\hline \multirow{4}{*}{ Port } & \multicolumn{10}{|c|}{ Passenger Flow } \\
\hline & \multicolumn{5}{|c|}{ Disembarked } & \multicolumn{5}{|c|}{ Embarked } \\
\hline & \multicolumn{5}{|c|}{ Year } & \multicolumn{5}{|c|}{ Year } \\
\hline & 2000 & 2002 & 2005 & 2010 & 2012 & 2000 & 2002 & 2005 & 2010 & 2012 \\
\hline Wanci & 47.158 & 28.784 & 34.582 & 42.033 & 54.963 & 47.064 & 27.222 & 32.649 & 38.369 & 50.426 \\
\hline Boepinang & 5.148 & 3.620 & 18.779 & 8.600 & 8.917 & 5.565 & 4.355 & 18.072 & 8.827 & 8.922 \\
\hline Kasipute & 6.830 & 8.156 & 9.499 & 29.138 & 44.220 & 5.480 & 4.687 & 12.301 & 26.010 & 33.772 \\
\hline Sikeli & 8.742 & 12.062 & 8.256 & 19.176 & 19.266 & 8.660 & 12.166 & 13.590 & 18.049 & 20.192 \\
\hline Talaga & 5.225 & 5.855 & 5.655 & 3.407 & 11.310 & 5.214 & 5.855 & 5.702 & 3.149 & 12.831 \\
\hline Lasalimu & 47.378 & 28.937 & 3.503 & 2.309 & 2.751 & 48.930 & 30.641 & 3.502 & 2.332 & 2.504 \\
\hline Kaledupa & 3.413 & 4.027 & 2.510 & 2.818 & 7.926 & 3.011 & 3.148 & 2.478 & 3.185 & 6.592 \\
\hline Tomia & 3.972 & 2.980 & 3.026 & 4.054 & 8.978 & 3.380 & 2.448 & 4.295 & 4.293 & 7.459 \\
\hline Binongko & 114 & 180 & - & 986 & 1.277 & 21 & 109 & - & 1.206 & 1.458 \\
\hline $\begin{array}{l}\text { Jembatan } \\
\text { Batu }\end{array}$ & 7.239 & 7.855 & - & - & - & 7.054 & 8.030 & - & - & . \\
\hline PT. ASDP & & & 158,139 & 111,985 & 168,337 & & & 122,889 & 110,669 & 155,084 \\
\hline
\end{tabular}

Source: Murhum Baubau Port Administration 2012c.

According to Table 4, it can be seen that the highest passenger mobility volume was dominated by four ports namely PT. ASDP, Wanci, Kasipute, and Sikeli. The port of PT. ASDP is in Baubau, \pm 600 meters to the Port of Murhum Baubau. This port serves the Baubau-Wamengkoli route which is located on Muna Island. Passenger mobility continued to increase. Passengers who disembark through the Port of PT. ASDP was more than who embarked. This condition was caused by residents of Muna Island wanting to travel to eastern or to western of Indonesia or migrate abroad, through the Port of Murhum Baubau. From 2005 to 2012, the mobility of passengers who disembarked at the Port of Wanci and Kasipute was more than those who embarked, while the number of passengers who embarked or left Kabaena Island at the Port of Sikeli was more than those who disembarked because residents of the island had a lot of expectations on overseas land.

\section{Mobility of Goods to Abroad Passing the Port of Murhum Baubau, 2009-2012}

In addition to serving goods and domestic mobility, the Port of Murhum Baubau also serves goods mobility abroad. Mobility of goods abroad is one of the causes of the increasing amount of outgoing cargo passing the Port of Murhum Baubau. Before 2008, the mobility of loading and unloading was more. Furthermore, from 2008 to 2012, the mobility of loading and unloading goods passing the Port of Murhum Baubau was far more.

Mobility of goods abroad through the Murhum Baubau Port has been around since 2005 with a total of 25 ship visits annually but with a very low load of 30 tons (Murhum Baubau Port Administration 2011, 12). In 2006, the number of ship visits was 14 times with a total load of 9,343.35 tons consisting of 9,347 tons of Asphalt and live fish of 16.35 tons (Murhum Baubau Port Administration 2006). Furthermore, in 2007 there was an increase in the number of cargoes by 66,510 tons with a number of foreign ship visits of 14 times (Murhum Baubau Port Administration 2007).

The decline and increase in the amount of mobility of goods abroad was affected by several aspects. First, the number of ship visits was: in 2009 as many as 40, 2010 as many as 28, 2011 as many as 67 , and 2012 as many as 84 . Second, the amount of mining and marine production in which 
quite a lot in 2009, then it decreased in 2010 but increased in 2011 and 2012. Third, export or loading commodities that was increasingly diversed. Fourth, an increase in the number of agents serving foreign shipping at the Port of Murhum Baubau. In 2009, there were four agents including PT. Mandiri fleet with the status based in Baubau with Yance Kongres as the person in charge, b. PT. Indo Dharama Transport with the status as branch with Bayu Wardana as the person in charge, $\mathrm{c}$. PT. Pelayaran Nasional Indonesia, d. PT. Anugrah Perkasa Bahari with the status as branch and Muh. Adios as person in charge, in 2010 the number of agents increased by one namely PT. SYNE, in 2011 the agents increased by three namely PT. PEI, PT. TRI, and PT. Aksar Saputra Lines with the status of a branch with Rudi Maturbongs as the person in charge (Murhum Baubau Port Administration 2012d). Furthermore, in 2012 the agents increased by two, namely PT. ST and PT. DDS.

\section{Conclusions}

The mobility of goods and people passing the Port of Murhum Baubau in the period of 1988 to 2012 experienced developments in various aspects. First, the number of ship visits annually had increased both ships serving routes in the Southeast Sulawesi region, nationally, and international ships. Second, the number of mobility of goods loading and unloading experienced a fluctuating increase and experienced an increase in volume especially in terms of productivity as seen from 2008 to 2012. This situation also changed the mobility of goods in the Port of Murhum Baubau from consumers to producers. One of the reasons was the existence of new ports that facilitate inter-island shipping and trading activities in the Southeast Sulawesi Islands. Third, the mobility of passengers who embarked at the Port of Murhum Baubau would always be much higher than that of the passengers who disembarked at the Port of Murhum Baubau. The number of passengers who embarked and disembarked at the Port of Murhum Baubau from 1988 to 1999 had a fluctuating increase in 11 years. The number of passengers who embarked were 2,011,571 people and passengers who disembarked were 1,831,380 people. A total of people who did not return were 180,191. However, this situation had changed, the number of passengers who disembarked at the Port of Murhum Baubau from 2001 to 2005 was far more than the passengers who embarked or left the Port of Murhum Baubau. This condition was certainly different from the period of 1988 to 1999. The increase in the number of passengers disembarking at the Port of Murhum Baubau was caused by inter-religious conflicts in Maluku in 1999-2001. Increased passenger flow who embarked more than who disembarked occurred again in 2006 to 2012. This happened due to the conflict that had died down. Although in 2001 to 2005 the number of passengers disembarked was more than passengers who embarked. Fourth, the mobility of goods and people from local ports to Baubau was greatly affected by the geographical location of the local port and would change both in terms of mobility of goods and in terms of passenger mobility in different periods. Fifth, mobility of goods abroad in the period 2009 to 2010 had decreased. This was due to the number of ship visits had decreased and the production volume was still greatly minor. However, in the period 2010 to 2012, it experienced great increase. This was due to the increased number of ship visits, the amount of mining material production as well as increased sea products, then the number of agents continued to increase as well each year.

\section{References}

Baubau Regional Government. 2007. Kota Baubau dalam Angka 2006/2007. Baubau: Badan Pusat Statistik Kota Baubau.

Dhakidae, Daniel. 2003. Profil Daerah Kabupaten dan Kota, Jilid 3. Jakarta: Penerbit Buku Kompas.

Directorate General of Sea Transportation Regional Office VI Kesyabandaran Baubau. 1985. DataData Pelabuhan. Baubau: Kantor Wilayah VI Kesyabandaran Baubau.

Fariastuti. 2002. "Mobility of People and Goods across the Border of West Kalimantan and Sarawak." Antropologi Indonesia 67: 94-104. https://doi.org/10.7454/ai.v0i67.3432

Gondhokusumo, Tuti Triyanti. 1982. Pengangkutan Melalui Laut I. Semarang: Fakultas Hukum Universitas Diponegoro.

Hamid, A. Rahman. 2013. Sejarah Maritim Indonesia. Yogyakarta: Penerbit Ombak. 
Lapian, A. B. 1974. Kata Pengantar dalam Teori dan Sejarah Kepulauan Indonesia. Jakarta: Bhratara. Lasse. 2015. Manajemen Bisnis Transportasi Laut, Carter, dan Klaim. Jakarta: Rajawali Press.

Murhum Baubau Port Administration. 1989. "Data untuk Bahan Laporan Kepada Kepala PT. Pelayaran Nasional Cabang Baubau. Dengan Nomor Surat 55/2/1367.” Baubau: Pemerintah Kabupaten Daerah Tingkat II Buton Sekretariat Wilayah.

Murhum Baubau Port Administration. 1999. "Data Kegiatan Angkutan Laut pada Kantor Pelabuhan Murhum Baubau Tahun 1988-1999.” Baubau: Kantor Pelabuhan Baubau.

Murhum Baubau Port Administration. 2006. "Laporan Kegiatan Operasional Harian Pelabuhan (T.II.UPT) Tahun 2006.” Baubau: Kantor Pelabuhan Murhum Baubau.

Murhum Baubau Port Administration. 2007. "Rekapitulasi Laporan Bulanan Tahun 2007.” Baubau: Kantor Pelabuhan Murhum Baubau.

Murhum Baubau Port Administration. 2011. "Laporan Kegiatan Pelaksanakan Tugas dan Fungsi (TUPOKSI) 2005.” Baubau: Direktorat Jenderal Perhubungan Laut Kantor Unit Penyelengara Pelabuhan Kelas I Baubau.

Murhum Baubau Port Administration. 2012a. "Data Kantor Unit Penyelenggara Pelabuhan Kelas I Baubau.” Baubau: Kantor Pelabuhan Murhum Baubau.

Murhum Baubau Port Administration. 2012b. "Data Kegiatan Angkutan Laut pada Kantor Pelabuhan Murhum Baubau Tahun 2001-2002 dan Baubau dalam Angka Tahun 2003-2012.” Baubau: Kantor Pelabuhan Baubau.

Murhum Baubau Port Administration. 2012c. "Kegiatan Angkutan Laut pada Kantor Pelabuhan/Satuan Kerja 2000-2012.” Baubau: KA. Sub. Seksi Kepelabuhanan.

Murhum Baubau Port Administration. 2012d. "Data Kegiatan Angkutan Laut Harian Kantor Pelabuhan Murhum Baubau KA. Sub. Seksi Kepelabuhanan Tahun 2009-2012.” Baubau: Kantor Pelabuhan Baubau.

Naim, Mochtar. 1973. Merantau Pola Migrasi Suku Minangkabau. Yogyakarta: Gadjah Mada University Press.

Rabani, L. O. 2010. Kota-Kota Pantai di Sulawesi Tenggara. Yogyakarta: Penerbit Ombak.

Sudjiton, et al. 2012. Perjalanan Kota Baubau Upaya Menemukan Hari Jadi, M. Mu'min Fahimuddin et al., editor. Baubau: BAPPEDA Kota Baubau.

Sulistiyono, Singgih T. 2003. The Java Sea Network: Patterns in the Development of Interregional Shipping and Trade in the Process of National Economic Integration Indonesia, 1870s-1970s. Proefschift ter verkrijging van de graad van Doktor aan de Universiteit Leiden.

The Central Bureau of Statistics of Baubau. 1995. Transportasi Antar Kecamatan dan Desa Kabupaten Buton 1994. Baubau: Badan Statistik Kota Baubau.

The Central Bureau of Statistics of Baubau. 2005. Baubau dalam Angka Tahun 2004. Baubau: Badan Pusat Statistik Kota Baubau.

The Central Bureau of Statistics of Baubau. 2009. Baubau dalam Angka Tahun 2007-2009. Baubau: Badan Pusat Statistik Kota Baubau.

Van Klinken, Gerry. 2007. Perang Kota Kecil, Kekerasan Komunal dan Demokratisasi di Indonesia. Jakarta: KITLV-Jakarta dan Yayasan Obor Indonesia.

Wallace C. 1999. "Crossing Borders: Mobility of Goods, Capital and People in the Central European Region.” In Global Futures. Explorations in Sociology, edited by Brah A., Hickman M.J., an Ghaill M.M. (eds) Palgrave Macmillan, London. https://doi.org/10.1057/9780230378537 10

Zuhdi, Susanto. 2014. Jejak Orang Butun dalam Sejarah Maritim Indonesia dalam Susanto Zuhdi, et al., Nasionalisme, Laut, dan Sejarah. Depok: Penerbit Komunitas Bambu.

Zuhdi, Susanto. 2018. Sejarah Buton yang Terabaikan: Labu Rope Labu Wana Edisi Revisi. Jakarta: Penerbit Wedatama Widya Sastra. 